Article

\title{
Study of High Power Ultrasound for Oak Wood Barrel Regeneration: Impact on Wood Properties and Sanitation Effect
}

\author{
Marion Breniaux ${ }^{1, *}$, Philippe Renault ${ }^{1,2}$, Fabrice Meunier ${ }^{3}$ and Rémy Ghidossi ${ }^{1}$ \\ 1 Université Bordeaux, ISVV, EA 4577, Unité de recherche Enologie, F-33882 Villenave d'Ornon, France; \\ philippe.renault33@gmail.com (P.R.); remy.ghidossi@u-bordeaux.fr (R.G.) \\ 2 Dyogena, 33290 Blanquefort, France \\ 3 Amarante Process, ADERA, 33600 Pessac, France; fabrice.meunier@u-bordeaux.fr \\ * Correspondence: marion.breniaux@u-bordeaux.fr; Tel.: +0033-5-57-57-58-58
}

Received: 21 December 2018; Accepted: 16 January 2019; Published: 1 February 2019

check for updates

\begin{abstract}
This study aims to investigate the ability of high power ultrasound (HPU) to ensure oak barrel sterilization and wood structure preservation. Optimization was performed in terms of temperature and time and the impact of the HPU process on the porous material was also characterized. In this research, several wood characteristics were considered, such as the specific surface area, hydrophobicity, oxygen desorption and spoilage microorganisms after treatment. The study showed that the microbial stabilization could be obtained with HPU $60{ }^{\circ} \mathrm{C} / 6 \mathrm{~min}$. The results obtained show that microorganisms are impacted up to a depth of $9 \mathrm{~mm}$, with a Brettanomyces bruxellensis population $<1 \log \mathrm{CFU} / \mathrm{g}$. The operating parameters used during the HPU treatment can also impact on wood exchange surface and oxygen desorption kinetics indicating that tartrate is removed. Indeed, the total oxygen desorption rate was recovered after HPU treatment, close to a new oak barrel, and thus may indicate that there is no impact on the ultrastructure (vessel, pore size or rays). Finally, wood wettability can also be impacted, depending on the temperature and the duration of exposure.
\end{abstract}

Keywords: high power ultrasound; wine aging; regeneration; sanitation; brettanomyces; oak wood barrel

\section{Introduction}

Aging red wines can be carried out in barrels to allow olfactory and gustatory modifications [1-4]. However, when aging takes place in wooden barrels, some organoleptic deviations may appear referred to as "brett flavor", referring to "stable", "leather", "manure" or "horse sweat". Bacteria and yeasts can penetrate into the wood to the same depth as the wine (close to $8 \mathrm{~mm}$ ) [5] and then contaminate other wines if the oak barrels are not sterilized properly [6], even if polyphenols have a negative impact on bacteria viability [7]. Brettanomyces can provide organoleptic deviations due to production of undesirable compounds, such as 4-ethylphenol and 4-ethylgaiacol [8]. These molecules can deteriorate the wine quality [9]. To avoid such deviations, several treatments can be employed in wineries. However, Yap et al. [10] have argued that hot water and chemical treatments (the two treatments most commonly used) may be ineffective against the Brettanomyces spoilage yeast [11,12]. Several types of treatments are used in wineries to sanitize barrels, such as chemical agents (sulfur dioxide, ozone) or physical agents, with UV radiation, hot water, microwaves and ultrasounds showing varying levels of efficiency $[5,11,13]$. For example, microwave treatment enables only a $35 \%$ reduction in the Brettanomyces spp. population [14]. Guzzon et al. [13] studied the efficacy of aqueous steam, UV irradiation, gaseous, and aqueous $\mathrm{O}_{3}$ for sterilizing oak barrels. Steam and $\mathrm{O}_{3}$ were demonstrated to 
be the most effective treatments, eliminating as much as $90 \%$ of yeasts. Nevertheless, in this case, total sanitation is not completely ensured because the treatment is only carried out on the stave surface. Due to the porous nature of wood and the limited transmittance of UV radiation, this process appears to be ineffective. With regards to the steam treatment, some authors have shown that the microorganism inhibition is linked to the wood depth. A reduction of $3 \mathrm{log}$ can be observed for depths of less than $3 \mathrm{~mm}$, and $2 \log$ if the depth is between 3 and $6 \mathrm{~mm}$ [15]. None of these processes are therefore completely effective and sulfur dioxide in wines should be managed carefully to avoid contamination.

Studies of the use of high power ultrasound (HPU) in industrial processes has recently been published [16,17]. In this process, electrical energy can be converted into ultrasound $(20 \mathrm{kHz}-10 \mathrm{MHz})$ at frequencies higher than those audible by the human ear $(16-20 \mathrm{kHz})$. High power ultrasound is characterized by intensities in excess of $1 \mathrm{~W} / \mathrm{cm}^{2}$ and frequencies between 20 and $100 \mathrm{kHz}$ [18-20]. When they are emitted in a liquid, this process forms high-energy micro bubbles (acoustic cavitation phenomenon) [21-23]. These cavitation bubbles generate very high temperatures locally (close to $80^{\circ} \mathrm{C}$ ) and pressures greater than $50 \mathrm{MPa}$ [19]. These micro cavitation bubbles (diameters around $1 \mu \mathrm{m}$ ) act homogeneously throughout the fluid (Pascal's law) and can penetrate deeply into the pores of the wood. Piyasena et al. [24] showed that the cavitation phenomenon generated by HPU can kill microbial cells by cell disintegration in many cases [24]. The effect of ultrasound on the growth and viability of pathogenic bacteria such as Escherichia coli, Pseudomonas fluorescens, several yeast like Saccharomyces cerevisiae, Brettanomyces, as well as various fungi, algae and protozoa, has been summarized by Jiranek et al. [25]. These authors consider that the rate of inactivation of microorganisms varies with the power [26-28] and frequency [29] of the ultrasound applied. Thus, according to Tsukamoto et al. [28], the wave amplitude has a large influence on the inactivation rate for S. cerevisiae cells. According to Borthwick et al. [29], cell disruption in this species is greater at high frequencies ( $267 \mathrm{kHz}$ compared to $20 \mathrm{kHz}$ for the same exposure time). In addition, HPU and thermal treatments $\left(45-60^{\circ} \mathrm{C}\right)$ have synergistic effects on the inactivation of microorganisms [30].

The potential application of HPU technology in the wine industry has also been assessed by Yap et al. [10] and Jiranek et al. [25]. These authors argued that this process could be used for the management of microorganisms at different stages of winemaking. Yap et al. [31] studied the effect of HPU on wood barrels and noticed that HPU removes Brettanomyces spp. on the barrel surface and in the stave up to a depth of $4 \mathrm{~mm}$.

Validation tests carried out in 2007 and 2008 by the Australian Wine Research Institute (AWRI) demonstrated that the cleaning and disinfection of barrels (American oak) using HPU technology was more efficient than with steam in conventional conditions of use $\left(1000 \mathrm{psi} / 6900 \mathrm{kPa}\right.$ at $60^{\circ} \mathrm{C}$ for $5 \mathrm{~min}$ ). In this research, the HPU not only removed all the deposited tartrate, but also inhibited $100 \%$ of Brettanomyces cells on the surface and up to $4 \mathrm{~mm}$ deep in the wood [31]. However, microorganisms can be located deeper in the oak wood (close to $8 \mathrm{~mm}$ ) and the impact of this treatment on the oak wood structure was not apprehended. Moreover, there were no optimization parameters for the HPU treatment in this study.

Recently, Porter et al. [32] studied the effect of HPU treatment on porous cleaning efficacy in American oak wine barrels using X-ray tomography. It was demonstrated that HPU can significantly remove tartrate deposits from the first two millimeters of oak surfaces, but this was not reproducible at a depth of 2-8 $\mathrm{mm}$. An average of $89 \%$ total tartrate volume was removed from the surface layer in the first treatment, but this was further increased to $98 \%$ by increasing temperature and time treatment. A highly significant removal of stave surface tartrate crystals was also demonstrated with this cleaning technique at the temperatures studied. Only a few studies considered the oak wood characteristics after HPU treatment, even if oak is a fragile matrix. Oak wood consists of macromolecules such as cellulose, hemicellulose and extractive compounds like ellagitannins, lignin and aromatic precursors. Cellulose and hemicellulose are complex components in the cell wall of wood and make up a large part of oak wood composition (more than 50\%). Hemicellulose is formed from covalent bonds with lignin (close to $30 \%$ of the total composition) and ester linkage with acetyl units and hydroxycinamic acids. 
These bonds are important to ensure the mechanical stability of the structure. These bonds limit the extraction of hemicellulose from the cell wall matrix. The application of ultrasound in extraction and refining processes has drawn increasing attention recently for several applications, and these studies prove that HPU could have a significant impact on cell wall structure [33]. Furthermore, ultrasonic treatment is well established in the processing of plant raw materials, in particular, in extracting low molecular weight substances and pharmaceutically active compounds $[34,35]$. The authors also consider that HPU could be used to extract cellulose from several plant materials and this aspect is essential for our work. The mechanochemical effect of ultrasound is believed to accelerate the extraction of organic compounds from plant materials due to the disruption of cell walls.

The innovative point of this study is the characterization of the porous material by evaluating the specific surface, oxygen desorption rate, and hydrophobicity of the oak wood after treatment. These parameters are very important as a modification of the oak wood structure could induce several modifications (wettability, oxygen desorption). Indeed, wine might penetrate deeper if the specific surface area and hydrophobicity are changed. Thus, microorganisms could also penetrate further into the depth of the wood and oxygen desorption could be more important. These measurements could ensure that no modifications of the oak wood structure (on the surface and at a depth) are induced by HPU.

The aim of this work was to study the effect of different operating conditions (temperature and time) for HPU treatment on wood properties and sanitation effect. The study investigated the impact of high power ultrasound (HPU) on (i) the specific surface (B.E.T method); (ii) the oxygen desorption kinetics contained in the wood; (iii) the oak wood hydrophobicity (contact angle) and (iv) spoilage microorganism (Brettanomyces bruxellensis) removal. All these indications could provide insights into oak wood structure and sanitation possibilities up to $9 \mathrm{~mm}$. Operating parameter optimization was performed in the first part and the microbial stabilization was carried out on with the optimized HPU parameters and the classical barrel treatment (steam) in the second part.

\section{Materials and Methods}

\subsection{Barrel Treatment}

\subsubsection{High Power Ultrasound (HPU)}

The HPU treatment process consisted in filling the barrel with water (heated to 40,60 or $80{ }^{\circ} \mathrm{C}$ by an autonomous system) and then to inserting the sonotrode (Dyogéna, Blanquefort, France) (part that emits the ultrasound waves) into the bung hole (Figure 1), thereby allowing pressurization of the water inside the barrel (0.3 bar). HPU was emitted inside the barrel (frequency $20 \mathrm{kHz}, 3.8 \mathrm{~kW}$ ). The experimental barrel used for the HPU treatment was made in order to place and maintain the experimental staves inside the barrel (Figure 2). The hatch of the experimental barrel was closed for water filling.

HPU experiments were carried out to characterize the influence of operating conditions: temperature and time. 


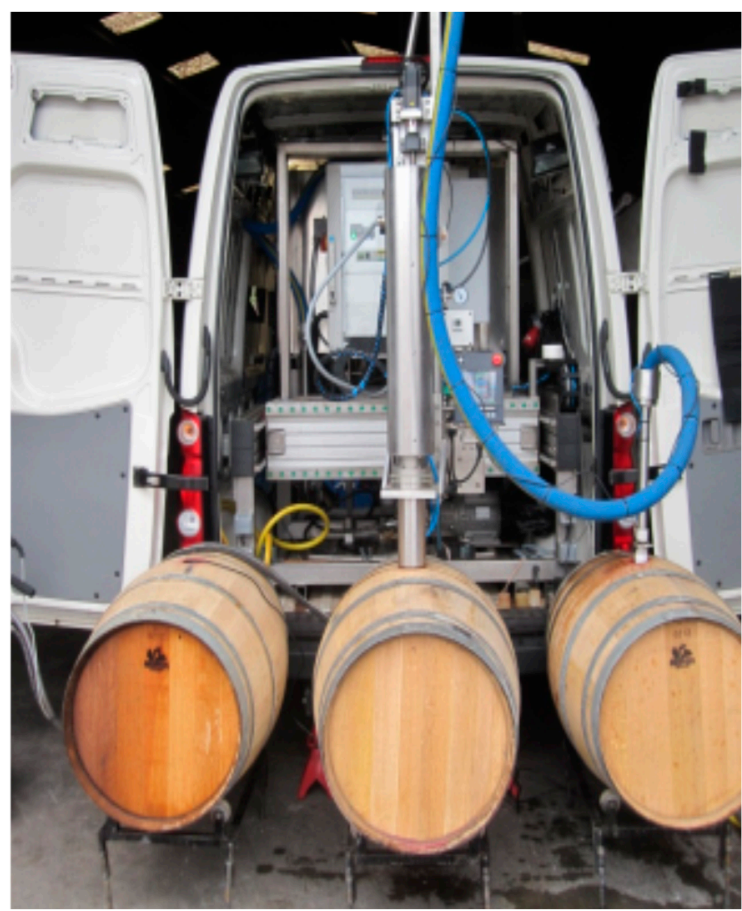

Figure 1. High power ultrasound (HPU) apparatus.

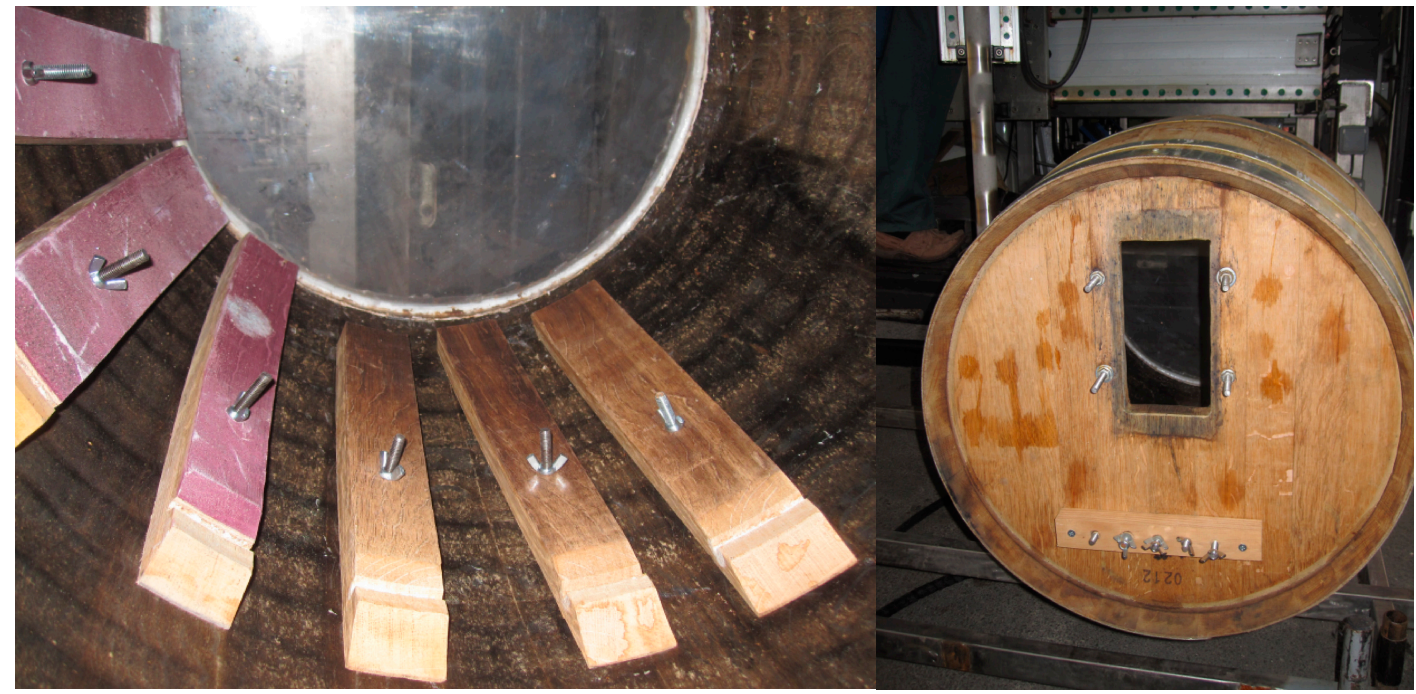

Figure 2. Experimental barrel for HPU treatment.

\subsubsection{Aqueous Steam Treatment}

The treatment by aqueous steam was carried out with an autonomous boiler Barriclean ${ }^{\circledR}$ (Bouyoud Distribution, Brive-la-gaillarde, France) supplying pressurized hot water during $10 \min \left(1.1 \mathrm{bar}, 110{ }^{\circ} \mathrm{C}\right)$ inside the barrel. Steam modalities were only used to compare results for microbiological aspects.

\subsection{Lab Experimental Setup and Operating Conditions}

The operating conditions investigated for HPU were processing time $(4,6$ or $8 \mathrm{~min})$ and temperature $\left(40,60\right.$ or $\left.80{ }^{\circ} \mathrm{C}\right)$. The staves for testing were extracted from French oak barrels with a medium toast used during two years. The study was carried out on 10 types of stave in triplicate, after undergoing various HPU treatments. The control staves were untreated. All the operating conditions 
are summarized in Table 1. The staves were then cut in different ways to obtain the appropriate sample size for each analysis. All the experiments were carried out in triplicate.

Table 1. Operating condition testing and experimental design.

\begin{tabular}{|c|c|c|c|}
\hline Treatment Temperature $\left({ }^{\circ} \mathrm{C}\right)$ & Treatment Time (min) & Liquid Used for Treatment & HPU Power (kW) \\
\hline & 4 & & \\
\hline \multirow[t]{3}{*}{40} & 6 & & \\
\hline & 8 & & \\
\hline & 4 & & \\
\hline \multirow[t]{3}{*}{60} & 6 & water & 3.8 \\
\hline & 8 & & \\
\hline & 4 & & \\
\hline \multirow[t]{3}{*}{80} & 6 & & \\
\hline & 8 & & \\
\hline & \multicolumn{3}{|c|}{ No treatment } \\
\hline
\end{tabular}

\subsection{Oak Wood Characterization}

\subsubsection{Determination of Specific Surface}

Knowledge of the specific surface of a wood sample (from a stave) is an important parameter to appreciate the exchange surface between the wood and wine. The specific surface refers to the real area of an object, as opposed to its apparent surface area. This is estimated from the amount of nitrogen adsorbed in relation to its pressure at the boiling point of liquid nitrogen and at normal atmospheric pressure.

The SA 3100 BET (Beckman Coulter, Brea, CA, USA) measures the specific surface of granulated samples via gas adsorption using the Brunauer-Emmett-Teller (BET) method. In this so-called discrete method, the data points obtained and the gas pressures are balanced before the reading is recorded. The volume of adsorbed gas retained by the sample is calculated from the pressures recorded at each measuring point.

\subsubsection{Oxygen Desorption Staves}

Several $500 \mathrm{~mL}$ flasks $\left(\right.$ Schott $\left.{ }^{\circledR}\right)$ were connected to a vacuum system generating a negative pressure of 0.2 bars. This negative pressure is comparable to that observed in the barrel. In the barrel, the $225 \mathrm{~L}$ of wine are in contact with the $2 \mathrm{~m}^{2}$ of the internal surface of the barrel. In order to simulate the real conditions, the volume surface ratio was respected by introducing an exchange surface of $36.3 \mathrm{~cm}^{2}$ of wood into each bottle filled with the model solution $(12 \%$ ethanol v/v, $5 \mathrm{~g} / \mathrm{L}$ tartaric acid and $\mathrm{pH}$ 3.5), made inert beforehand with nitrogen. The external surfaces of the two oak pieces $(7.25 \mathrm{~cm} \times 2.5 \mathrm{~cm})$ were covered with silicone gel (Elastosil E43), with the exception of the inner side (toasted side) to reproduce the real conditions in an oak barrel. The inert model solution was changed every 6 days. This methodology was used to avoid the oxygen consumption of the released oak wood polyphenols [36]. Preliminary tests were realized to ensure that no oxygen transfer could occur through the silicone gel. The oxygen desorption kinetics of the wood pieces were monitored every day for 1 month. The oxygen concentration in the liquid flask was detected using a mobile optical fiber coupled with a sensor device. The luminescent system was of the Oxy-trace type (PreSens $\mathrm{GmbH}$, Germany), coupled with a PSt3 type oxygen sensor (detection limit $=15 \mu \mathrm{g} / \mathrm{L}, 0-100 \%$ oxygen). The spot sensors were placed inside the liquid flask allowing detection of the oxygen concentration.

\subsubsection{Contact Angle Measurement}

The sessile drop contact angle measurement technique seeks to determine the wettability of the staves studied by characterizing the ease of a liquid drop spreading over a solid surface. We characterized here the hydrophobic/hydrophilic nature of the material. The experimental device used was a Digidrop Contact Angle Meter (GBX Scientific Instruments, Ireland). A $20 \mu \mathrm{L}$ water droplet 
was placed on the stave and the contact angle was measured after stabilization for around $200 \mathrm{~s}$. The contact angle is defined as the angle between the solid surface and a tangent, drawn on the drop surface, passing through the atmosphere-liquid-solid triple point (Figure 3) [37]. An image system analysis integrates the angle as a function of time and makes it possible to determine whether the drop enters the material.

For each modality studied, the contact angles were calculated from measurements on three pieces of stave from three different parts of each stave. The drop was systematically in a place where there were no apparent residues of tartrate, to avoid any experimental artefacts. For each experimental modality, the average contact angle was thus obtained from 9 individual measurements on three different samples.

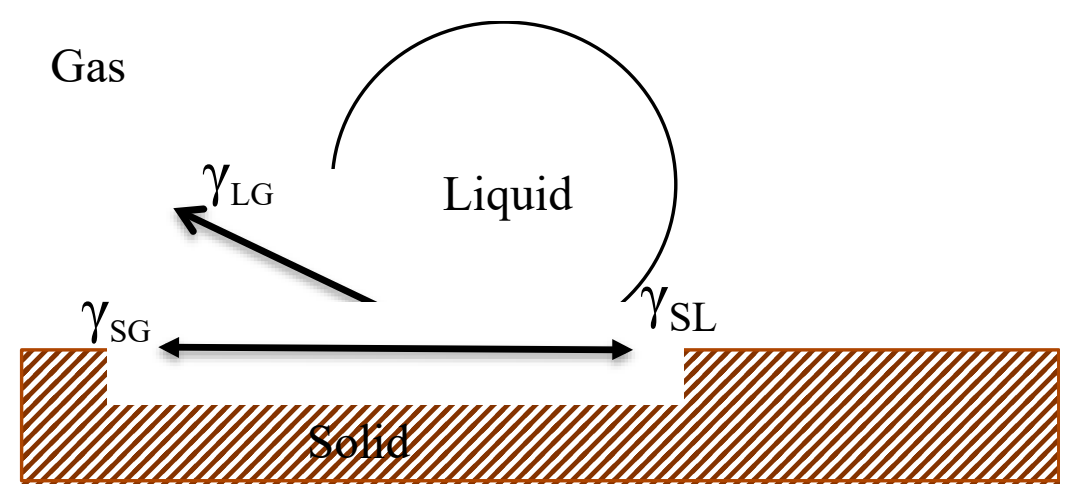

Figure 3. Schematic example of contact angle measurement.

\subsection{Impact on Microorganisms}

The impact of HPU on spoilage microorganisms, especially Brettanomyces bruxellensis, was investigated according to their depth in the wood.

The staves of French oak wood barrels of one or two years (medium toast) were incubated in a liquid culture of YPG (Yeast extract $10 \mathrm{~g} / \mathrm{L}$; bactopeptone $10 \mathrm{~g} / \mathrm{L}$; glucose $20 \mathrm{~g} / \mathrm{L}$; adjusted to $\mathrm{pH} 5$ ), supplemented with antibiotics in order to limit the growth of bacteria, molds and yeast of the Saccharomyces genus ( $0.1 \mathrm{~g} / \mathrm{L}$ chloramphenicol; $0.15 \mathrm{~g} / \mathrm{L}$ biphenyl; $0.5 \mathrm{~g} / \mathrm{L}$ cycloheximide), and containing B. bruxellensis L0539 (available through the "Centre de Ressources Biologiques CEnologiques" of Bordeaux University (CRBO)) in mid-exponential phase during 4 days at room temperature. The population was determined before and after treatment by drilling staves to different depths $(0-2 \mathrm{~mm} ; 2-5 \mathrm{~mm} ; 5-9 \mathrm{~mm})$ with a small drill bit and permits recovering $0.2 \mathrm{~g}$ of wood.

The wood samples recovered at different depths were incubated in $2 \mathrm{~mL}$ of sterile saline solution ( $9 \mathrm{~g} / \mathrm{L}$ sodium chloride) during $48 \mathrm{~h}$ at room temperature under agitation. Serial dilutions of these samples were plated on solid YPG (Yeast extract $10 \mathrm{~g} / \mathrm{L}$; bactopeptone $10 \mathrm{~g} / \mathrm{L}$; glucose $20 \mathrm{~g} / \mathrm{L}$; agar $20 \mathrm{~g} / \mathrm{L}$; adjusted to $\mathrm{pH}$ 5) supplemented with antibiotics $(0.1 \mathrm{~g} / \mathrm{L}$ chloramphenicol; $0.15 \mathrm{~g} / \mathrm{L}$ biphenyl; $0.5 \mathrm{~g} / \mathrm{L}$ cycloheximide). Yeast populations in the primary dilution were monitored by fluorescence microscopy.

Colonies were counted after 7 days of incubation at $30^{\circ} \mathrm{C}$. All assays were performed in triplicate.

\subsection{Statistical Analyses}

Statistical data were analyzed using the Kruskal-Wallis non-parametric test (RStudio software, v1.0.143, RStudio Inc., Boston, USA, http:/ /www.rstudio.com/) to identify the means that were significantly different. The statistically significant level was $5 \%(p<0.05)$. 


\section{Results and Discussion}

\subsection{Specific Surface Area}

The objective of this measurement is to characterize the specific surface area, which could have an impact on the liquid/solid exchange surface. The specific surface area of a wood sample (from a stave) could be defined as the total surface area of a material per unit of mass and has a particular importance for adsorption phenomena.

The specific surface area measured by the BET method for the different test modalities tested is presented in Figure 4. The specific surface area increases regardless of the HPU treatment modalities compared to the control (from $900 \%$ to $1400 \%$ ). There is no effect of the time treatment on the specific surface contrarily to temperature. Indeed, at high temperature $\left(80^{\circ} \mathrm{C}\right)$, we notice that the specific surface area was around $2 \mathrm{~m}^{2} / \mathrm{g}$, which is significantly lower than $40{ }^{\circ} \mathrm{C}$ and $60{ }^{\circ} \mathrm{C}$. These low values compared to other temperatures should indicate a wood modification of HPU treatment above $60{ }^{\circ} \mathrm{C}$. This deterioration of wood integrity could involve a degradation of lignin, cellulose and hemicellulose [38]. Moreover the increase in the specific area could also indicate that tartrate is effectively removed from the wood structure during HPU treatment, especially for $40{ }^{\circ} \mathrm{C}$ and $60{ }^{\circ} \mathrm{C}$, while remaining present in the untreated controlled staves. Figure 5 illustrates an example of tartrate removal from HPU treatment at $60^{\circ} \mathrm{C}$. However, the surface tartrate is more efficiently removed at $60^{\circ} \mathrm{C}$ and $80^{\circ} \mathrm{C}$, instead of $40^{\circ} \mathrm{C}$. These results corroborate those of Porter et al. [32], which showed $98 \%$ of total tartrate volume removed with HPU treatment $\left(4 \mathrm{KW}, 12 \mathrm{~min}\right.$ at $\left.40-60{ }^{\circ} \mathrm{C}\right)$.

Ultrasound treatment clearly modifies the physiochemical structure of wood because we notice significant differences between all the HPU modalities and the control. These considerations were also observed by He et al. [38]. These authors considered that HPU could decrease the alkali metals in the resulting material, and significantly increase its crystallinity. It has been observed in the case of eucalyptus, and our results indicate that the same trend is obtained for oak wood. The authors considered that a rupture appears between the methyl/methylene groups in cellulose and contributes to removing cellulose, hemicellulose and lignin.

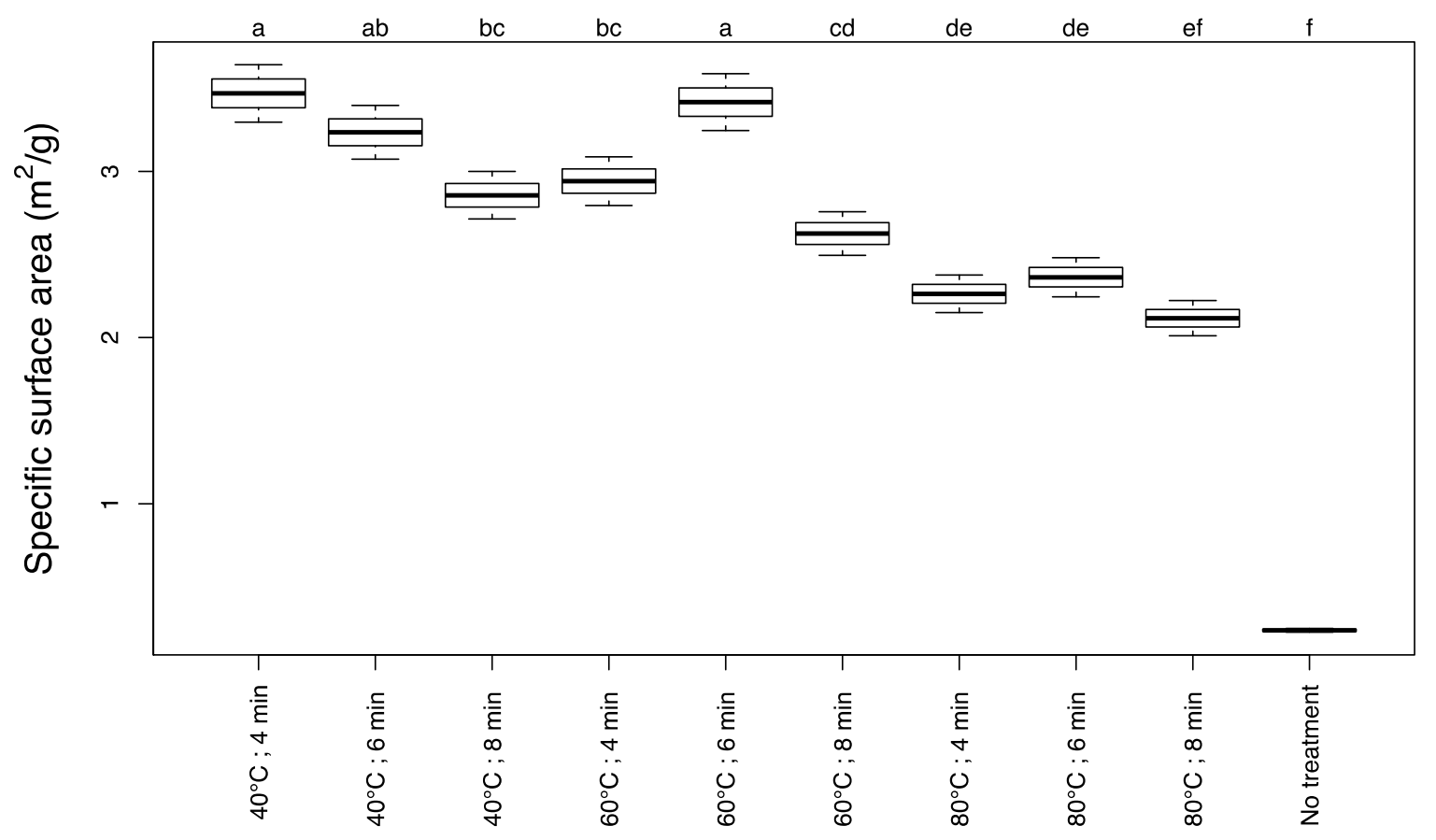

Figure 4. Specific surface of wood treated by HPU. 

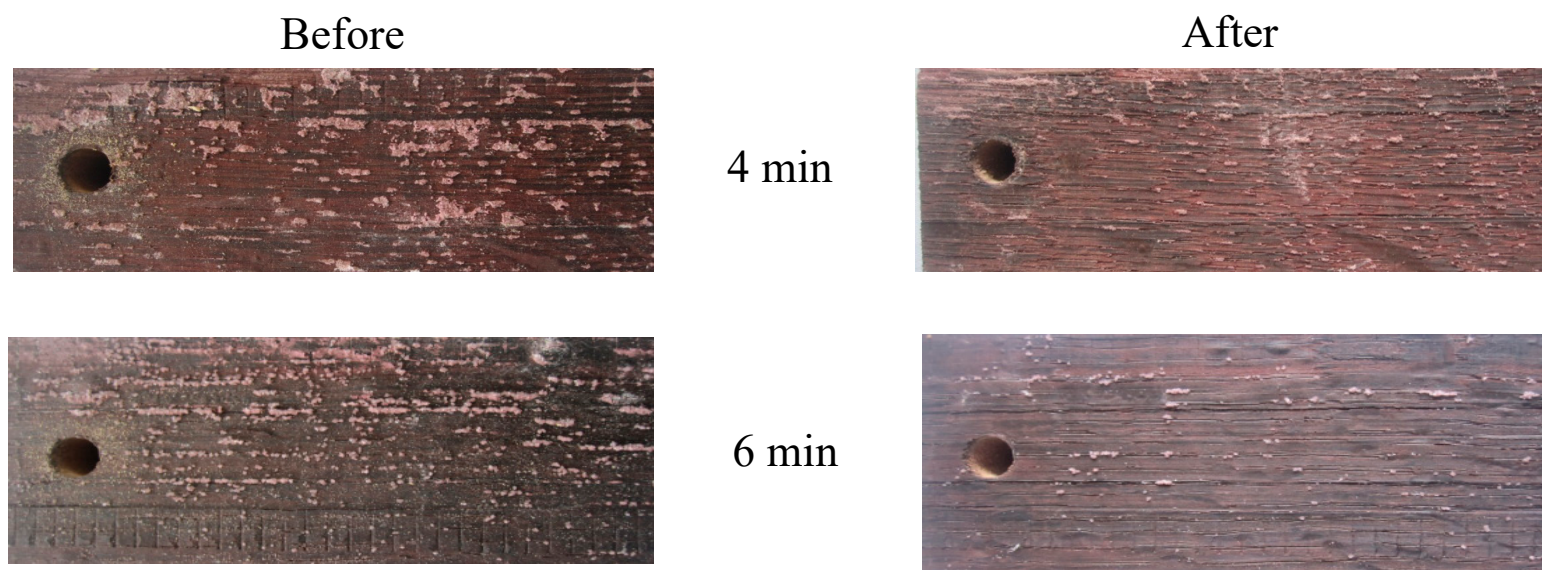

$6 \min$
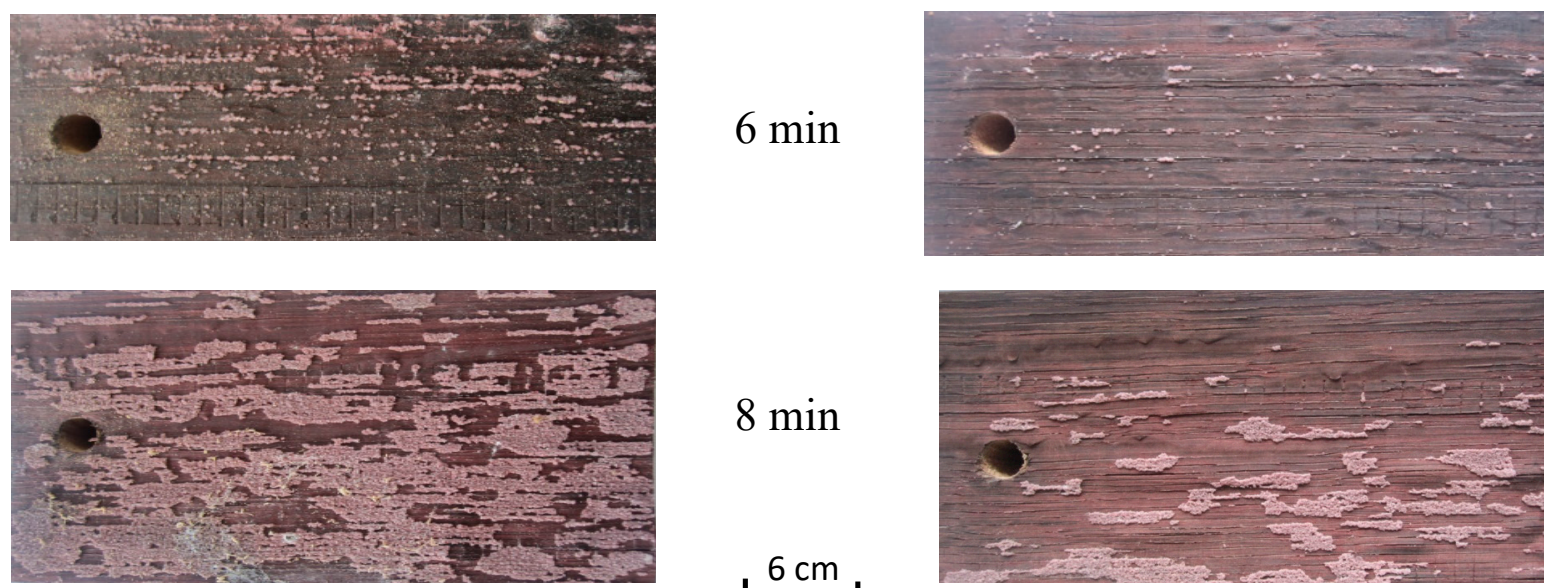

Figure 5. Examples of tartrate removal before and after HPU treatment $\left(60^{\circ} \mathrm{C}\right)$.

HPU also apparently increases the exposure of the material to the treatment solution and enhances its accessibility, as well as breaking down pits, which could generate collapses and micro channels, and removing attachments on the wood tissue. This aspect will have an impact on oxygen desorption and should be considered to validate our results. Finally, further investigation should be made on the specific surface deeper in the wood stave.

\subsection{Oxygen Desorption of Staves}

The influence of the HPU treatment on the quantity of oxygen desorbed and its kinetics was investigated with a specific vacuum system. The $\mathrm{O}_{2}$ desorption monitoring was carried out over 26 days for each treatment considered in triplicate. The results for HPU treatment at $60^{\circ} \mathrm{C}$ are presented in Figure 6.

We noticed that untreated staves desorbed less oxygen over the first 6 days. We could consider in this case that tartrate is still present in the oak wood vessels and thus could limit the oxygen desorption kinetic. For HPU treatment, in the first 6 days we noticed that $\mathrm{O}_{2}$ desorption is higher for $8 \mathrm{~min}$ than for 6 min at $60^{\circ} \mathrm{C}$. Then, over the next 6 days, we observed that desorption of HPU 6 min was slightly higher than HPU $8 \mathrm{~min}$, with a variation close to $0.5 \mathrm{mg} / \mathrm{L}$. We can see in Table 2 that there was no difference in total oxygen transfer over 26 days for HPU treatment between 6 and $8 \mathrm{~min}$. On the other hand, the total oxygen concentration desorbed was $5.57 \pm 1.25 \mathrm{mg} / \mathrm{L}$ for untreated stave, which was significantly lower than HPU. In comparison to results obtained by Qiu et al. [39], the $\mathrm{O}_{2}$ desorption rate for wood barrel during the first month was lower in this case (close to $10 \mathrm{mg} / \mathrm{L}$ for a new oak wood [36]). Considering other HPU temperatures $\left(40^{\circ} \mathrm{C}\right.$ and $\left.80^{\circ} \mathrm{C}\right)$, the same trend could be observed (results not shown).

Our results indicate that oxygen desorption is highly impacted by HPU treatment. In the case of untreated oak wood, the oxygen desorption rate was two times lower, as was kinetics, especially for the first week. After HPU treatment, the sum was close to $10 \mathrm{mg} / \mathrm{L}$ indicating a significant variation. These values are still similar to an unused oak wood, which indicates that the oak structure is not impacted. The hypothesis of the appearance of micro channels was not verified here for the HPU treatment at $60^{\circ} \mathrm{C}$. Oak wood ultrastructure seems to be conserved. 


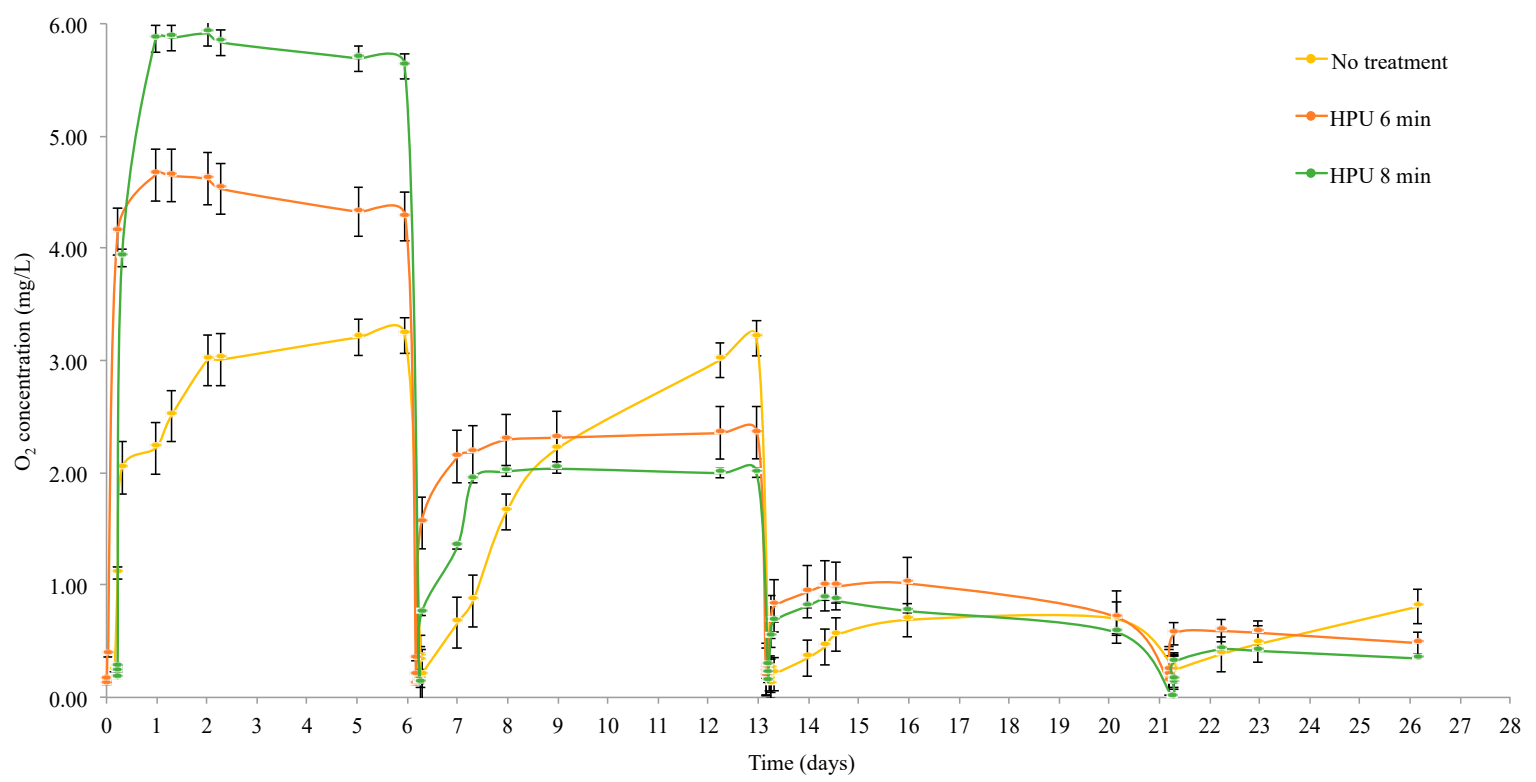

Figure 6. Influence of HPU treatment on $\mathrm{O}_{2}$ desorption.

Table 2. Total oxygen desorption for different type of treatment over 26 days. The total oxygen concentration is the sum of each mean oxygen value during each 6-day period previously shown in Figure 6.

\begin{tabular}{cc}
\hline Type of Treatment & Total Oxygen Concentration $(\mathrm{mg} / \mathrm{L})$ \\
\hline No treatment & $5.57 \pm 1.05^{\mathrm{a}}$ \\
HPU $60^{\circ} \mathrm{C}$ & $8.11 \pm 1.15^{\mathrm{b}}$ \\
$6 \mathrm{~min}$ & \\
$\mathrm{HPU} 60^{\circ} \mathrm{C}$ & $8.63 \pm 0.43^{\mathrm{b}}$ \\
$8 \mathrm{~min}$ &
\end{tabular}

Subscript letter refers to the significant differences between the types of treatment $(p=0.05)$.

\subsection{Contact Angle}

The purpose of this analysis was to characterize the hydrophobic/hydrophilic nature of the contact surface. The contact angle could indicate the modifications that may possibly occur at the structural level of the staves after HPU treatment. By definition, the smaller the contact angle, the higher the hydrophobicity, which could have an impact on the absorption rate.

The contact angle measurements for HPU treatments are presented in Figure 7. We could consider that the duration of treatment does not seem to have a decisive influence on the hydrophobic nature of the wood surface. However, we noticed a trend in the HPU effect with the global increase in contact angle values. In the other types of treatment, no significant difference was observed compared to the control, although we did notice an upward trend in the contact angle. These results suggest that wood samples are more hydrophobic and significant differences are observed for some cases $\left(80^{\circ} \mathrm{C}\right.$ and $40{ }^{\circ} \mathrm{C} / 6 \mathrm{~min}$ ). These differences are possibly related to lignin removal, the presence of hemicelluloses or other carbohydrate material and extractives at the fiber surface. These results are similar to those obtained by [33]. In our case, our results suggest that, HPU treatments and, more especially, high temperature $\left(80^{\circ} \mathrm{C}\right)$, could induce some modification because the contact angle is significantly different (higher than $50^{\circ}$ for each case). The results obtained are in good agreement with those observed for the main wood components, reported by Young [40]. The authors proved the wettability of wood pulp fibers where hardwood lignin (kraft) has a contact angle of $60^{\circ}$ and cellulose $33-34^{\circ}$. The authors consider that surfaces rich in lignin and extractives have higher contact angles, and the values obtained 
in this case were close to $60^{\circ}$. These values therefore indicate a greater proportion of extractives and lignin in the surface of oak wood, which is a more hydrophobic surface. The potential of ultrasound to extract polysaccharide components has been widely studied in different plants and plant tissues and this phenomenon is confirmed in our study. Ultrasounds are known to be a powerful tool for accelerating polysaccharide extraction. In our case, the extraction seems to be effective because the hydrophobic characteristics are increased in the case of HPU treatment at high temperature. This could indicate that polysaccharide content is also increased on the surface and their desorption will be higher. This parameter is essential because it will impact the oak wood wettability. In our case, the use of HPU generally led to an increase in the hydrophobicity of the wood (from 125\% to 350\%). Even if the link between wettability and $\mathrm{O}_{2}$ desorption kinetics exists from a theoretical point of view, it is difficult to extrapolate in our case and additional experiments should be conducted to validate this hypothesis.

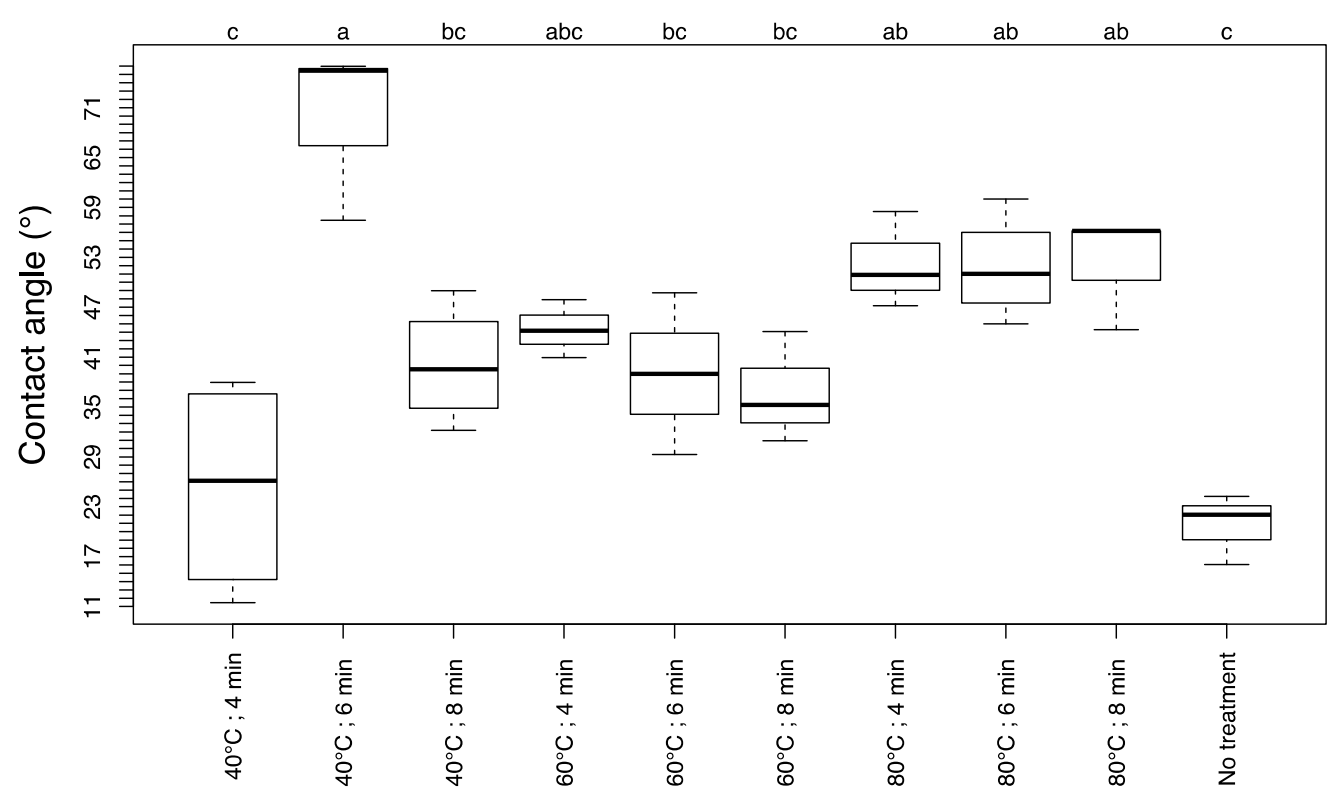

Figure 7. Influence of HPU treatments on wood hydrophobicity by contact angle measurements.

\subsection{Sanitation Effect on Spoilage Microorganism B. Bruxellensis}

Sanitation effects of two types of treatment (HPU $6 \mathrm{~min} / 60^{\circ} \mathrm{C}$ and steam $10 \mathrm{~min} / 110^{\circ} \mathrm{C}$ ) were investigated for the removal of the spoilage microorganism B. bruxellensis. Staves inoculated with B. bruxellensis were treated with HPU and different depth samples were recovered in order to estimate the effectiveness of the in-depth treatment as we can see in Table 3.

If we focus on HPU treatment $\left(6 \mathrm{~min} / 60^{\circ} \mathrm{C}\right)$, we notice that the post-treatment population of B. bruxellensis is lower than the detection limit ( $1 \log \mathrm{CFU} / \mathrm{g})$ to a depth close to $9 \mathrm{~mm}$. This length represents the maximum depth reached by the wine by passive diffusion in the wood during aging and therefore corresponds to the maximum depth reached by Brettanomyces yeast. This efficiency is probably due to the synergistic effect between the HPU treatment, especially cavitation bubbles, and the thermal effect of the water at $60^{\circ} \mathrm{C}$ brought into contact with yeast nested in the wood. On the other hand, we consider that steam treatment is less efficient because the post-treatment population of B. bruxellensis is unchanged from $2 \mathrm{~mm}$ to $9 \mathrm{~mm}$. The depth efficiency for steam treatment is $2 \mathrm{~mm}$ with a population lower than the detection limit. We could consider that these results are due to the thermal inertia of the wood. During steam treatment, the first millimeters of the wood reach a temperature close to $100^{\circ} \mathrm{C}$, allowing elimination of Brettanomyces yeasts, whereas the temperature only reaches $45^{\circ} \mathrm{C}$ at $5 \mathrm{~mm}$. We can also see that there is no difference in the treatment response (HPU or steam) between staves of 1 or 2 years. Yap et al. [31] have studied the effect of HPU on wood barrels and noticed that HPU removed Brettanomyces spp. on the barrel surface and in the stave up to 
$4 \mathrm{~mm}$, but they did not investigate to further depths. In comparison to another innovative treatment, González-Arenzana et al. [14] studied the microwaves capacity to sterilize French oak wood barrels and they were able to remove $35 \%$ of the population for Brettanomyces spp., $36 \%$ of total yeast, $90 \%$ of lactic acid bacteria and 100\% of acetic bacteria up to a depth $8 \mathrm{~mm}$ [14]. In our case with optimized operating parameters, the HPU sanitation effect reaches a depth of $9 \mathrm{~mm}$ in the wood, which is also the depth to which the wine and therefore Brettanomyces yeast can penetrate.

According to these results, the barrels contaminated by B. bruxellensis can be reused if they are treated with HPU $\left(3.8 \mathrm{~kW}, 6\right.$ min at $\left.60^{\circ} \mathrm{C}\right)$, unlike steam treatment that leaves viable B. bruxellensis cells in the depth of the wood, which can quickly become sources of recontamination. The HPU treatment is expected to target cells that are located deep within the pores of the staves, which would otherwise be untreated by classical barrel treatments.

Table 3. B. bruxellensis population before and after HPU or steam treatment on staves of one and two years at different sampling depth.

\begin{tabular}{|c|c|c|c|c|}
\hline Stave Age (year) & Type of Treatment & $\begin{array}{l}\text { Sampling Depth } \\
(\mathrm{mm})\end{array}$ & $\begin{array}{c}\text { B. bruxellensis } \\
\text { Population before } \\
\text { Treatment }(\log \text { CFU/g) }\end{array}$ & $\begin{array}{c}\text { B. bruxellensis } \\
\text { Population Post } \\
\text { Treatment }(\log \text { CFU/g) }\end{array}$ \\
\hline \multirow{6}{*}{1} & \multirow{3}{*}{$\begin{array}{l}\text { HPU } 6 \text { min } \\
\quad 60^{\circ} \mathrm{C}\end{array}$} & $0-2$ & $7.73 \pm 0.02$ & $<\mathrm{DL}$ \\
\hline & & $2-5$ & $5.89 \pm 0.04$ & $<\mathrm{DL}$ \\
\hline & & $5-9$ & $4.23 \pm 0.01$ & $<\mathrm{DL}$ \\
\hline & \multirow{3}{*}{$\begin{array}{l}\text { Steam } 10 \mathrm{~min} \\
110^{\circ} \mathrm{C}\end{array}$} & $0-2$ & $7.79 \pm 0.05$ & $<\mathrm{DL}$ \\
\hline & & $2-5$ & $5.71 \pm 0.03$ & $4.92 \pm 0.04$ \\
\hline & & $5-9$ & $4.63 \pm 0.02$ & $4.59 \pm 0.03$ \\
\hline \multirow{6}{*}{2} & \multirow{3}{*}{$\begin{array}{l}\text { HPU } 6 \text { min } \\
\quad 60^{\circ} \mathrm{C}\end{array}$} & $0-2$ & $8.11 \pm 0.04$ & $<\mathrm{DL}$ \\
\hline & & $2-5$ & $6.08 \pm 0.02$ & $<\mathrm{DL}$ \\
\hline & & $5-9$ & $5.61 \pm 0.01$ & $<\mathrm{DL}$ \\
\hline & \multirow{3}{*}{$\begin{array}{l}\text { Steam } 10 \mathrm{~min} \\
110^{\circ} \mathrm{C}\end{array}$} & $0-2$ & $7.91 \pm 0.05$ & $<\mathrm{DL}$ \\
\hline & & $2-5$ & $6.82 \pm 0.03$ & $5.96 \pm 0.02$ \\
\hline & & $5-9$ & $5.71 \pm 0.02$ & $5.63 \pm 0.03$ \\
\hline
\end{tabular}

$<$ DL: Detection limit $(1 \log \mathrm{CFU} / \mathrm{g})$.

\section{Conclusions}

This study has shown that the combined effect of HPU and heat treatment may have an impact on wood sanitation, the wettability of wood, its specific surface and oxygen transfer kinetics. The operating parameters used during the HPU treatment are essential.

Specific surface measurement seems to be a relevant method for determining the tartrate removal efficiency of wood. This method has good repeatability and is not influenced by the heterogeneity of the wood surface. Concerning the hydrophobicity of the wood, we have shown that HPU could increase the contact angle, especially at high temperatures $\left(80^{\circ} \mathrm{C}\right)$. Thus, the HPU treatment enables the initial oxygen transfer capacity of the wood to be partially recovered particularly because of the surface tartrate removal. Nevertheless, we could go further in the experiments by extending to different wood origin and types of barrels (age, toast, wine, wood grain) or by investigating the ultrastructure of the wood.

Finally, the sanitation effect of HPU was investigated and permits removal of all viable B. bruxellensis cells up to a depth $9 \mathrm{~mm}$ with processing parameters set at $60{ }^{\circ} \mathrm{C} / 6 \mathrm{~min}$ with 3.8 $\mathrm{kW}$. These parameters $\left(60^{\circ} \mathrm{C} ; 6 \mathrm{~min}\right)$ are the most efficient in regards to all of these issues.

Author Contributions: P.R. and R.G. conceived the experimental design; F.M. performed the contact angle, specific surface and oxygen desorption experiment; P.R. carried out the HPU and steam treatment, as well as the microbiology test; P.R. and R.G. supervised the experiments; P.R. and M.B. processed the results; M.B. wrote the paper: R.G., P.R. and F.M. reviewed the manuscript.

Funding: This research has been financed by the Region Aquitaine. 
Acknowledgments: The authors would like to thank Hancock Hutton Langues Services for the English corrections. We would like to thank Dyogena and the Region Aquitaine for the financial support.

Conflicts of Interest: The authors declare no conflict of interest.

\section{References}

1. Cerdán, T.G.; Ancín-Azpilicueta, C. Effect of oak barrel type on the volatile composition of wine: Storage time optimization. LTW Food Sci. Technol. 2006, 39, 199-205. [CrossRef]

2. Ortega-Heras, M.; González-Sanjosé, M.L.; González-Huerta, C. Consideration of the influence of aging process, type of wine and oenological classic parameters on the levels of wood volatile compounds present in red wines. Food Chem. 2007, 103, 1434-1448. [CrossRef]

3. Chira, K.; Teissedre, P.-L. Chemical and sensory evaluation of wine matured in oak barrel: Effect of oak species involved and toasting process. Eur. Food Res. Technol. 2014, 240, 533-547. [CrossRef]

4. González-Centeno, M.R.; Chira, K.; Teissedre, P.-L. Comparison between Malolactic Fermentation Container and Barrel Toasting Effects on Phenolic, Volatile, and Sensory Profiles of Red Wines. J. Agric. Food Chem. 2017, 65, 3320-3329. [CrossRef] [PubMed]

5. Malfeito-Ferreira, M.; Laureano, P.; Barata, A.; Antuono, I.D.; Stender, H.; Loureiro, V. Effect of different barrique sanitation procedures on yeasts isolated from the inner layers of Wood. In Proceedings of the ASEV 55th Annual Meeting, San Diego, CA, USA, 29-30 June 2004.

6. Cibrario, A. Diversité Génétique et Phénotypique de L'espèce Brettanomyces bruxellensis: Influence sur son Potentiel D'altération des Vins Rouges. Ph.D. Thesis, Université de Bordeaux, Bordeaux, France, 2017.

7. Breniaux, M.; Dutilh, L.; Petrel, M.; Gontier, E.; Campbell-Sills, H.; Deleris-Bou, M.; Krieger, S.; Teissedre, P.L.; Jourdes, M.; Reguant, C.; et al. Adaptation of two groups of Oenococcus oeni strains to red and white wines: The role of acidity and phenolic compounds. J. Appl. Microbiol. 2018, 125, 1117-1127. [CrossRef] [PubMed]

8. Chatonnet, P.; Dubourdieu, D.; Boidron, J.N.; Pons, M. The origin of ethylphenols in wines. J. Sci. Food Agric. 1992, 60, 165-178. [CrossRef]

9. Coulon, J.; Perello, M.C.; Funel, A.L.; de Revel, G.; Renouf, V. Brettanomyces bruxellensis evolution and volatile phenols production in red wines during storage in bottles. J. Appl. Microbiol. 2010, 108, 1450-1458. [CrossRef]

10. Yap, A.; Jiranek, V.; Grbin, P.; Barnes, M.; Bates, D. Studies on the application of high-power ultrasonics for barrel and plank cleaning and disinfection. Aust. N. Z. Wine Ind. J. 2007, 22, 96-104.

11. Conterno, L.; Joseph, C.; Arvik, T.; Henick-Kling, T.; Bisson, L.F. Genetic and physiological characterization of Brettanomyces bruxellensis strains isolated from wines. Am. J. Enol. Viticult. 2006, 57, 139-147.

12. Curtin, C.D.; Bellon, J.R.; Henschke, P.A.; Godden, P.W.; de Barros Lopes, M.A. Genetic diversity of Dekkera bruxellensis yeasts isolated from Australian wineries. FEMS Yeast Res. 2007, 7, 471-481. [CrossRef]

13. Guzzon, R.; Widmann, G.; Malacarne, M.; Nardin, T.; Nicolini, G.; Larcher, R. Survey of the yeast population inside wine barrels and the effects of certain techniques in preventing microbiological spoilage. Eur. Food Res. Technol. 2011, 233, 285-291. [CrossRef]

14. González-Arenzana, L.; Santamaría, P.; López, R.; Garijo, P.; Gutiérrez, A.R.; Garde-Cerdán, T.; López-Alfaro, I. Microwave technology as a new tool to improve microbiological control of oak barrels: A preliminary study. Food Control. 2013, 30, 536-539. [CrossRef]

15. Poupault, P.; Richard, R. Bio-Adhésion des Levures du Genre Brettanomyces et Conséquences sur L'hygiène de la Barrique. Matevi-France.com 2006, 76, 1-5. Available online: http: / / www.matevi-france.com/fileadmin/user_upload/fichiers_matevi/Autres_materiels_pdf/Bioadhesion_microbienne_et_hygiene_des_barriques_Matevi_2016.pdf (accessed on 5 December 2018).

16. Mawson, R.; Knoerzer, K. A brief history of the application of ultrasonics in food processing. In Proceedings of the 19th International Congress on Acoustics, Madrid, Spain, 2-7 September 2007.

17. Patist, A.; Bates, D. Ultrasonic innovations in the food industry: From the laboratory to commercial production. Innov. Food Sci. Emerg. Technol. 2008, 9, 147-154. [CrossRef]

18. McClements, D.J. Advances in the application of ultrasound in food analysis and processing. Trends Food Sci. Technol. 1995, 6, 293-299. [CrossRef]

19. Leighton, T. Ultrasound in Food Processing; Springer Science \& Business Media: Berlin, Germany, 1998.

20. Villamiel, M.; de Jong, P. Influence of high-intensity ultrasound and heat treatment in continuous flow on fat, proteins, and native enzymes of milk. J. Agric. Food Chem. 2000, 48, 472-478. [CrossRef] 
21. Maisonhaute, E.; Prado, C.; White, P.; Compton, R.G. Surface acoustic cavitation understood via nanosecond electrochemistry. Part III: Shear stress in ultrasonic cleaning. Ultrason. Sonochem. 2002, 9, 297-303. [CrossRef]

22. Krefting, D.; Mettin, R.; Lauterborn, W. High-speed observation of acoustic cavitation erosion in multibubble systems. Ultrason. Sonochem. 2004, 11, 119-123. [CrossRef]

23. Leighton, T. What is ultrasound? Prog. Biophys. Mol. Biol. 2007, 93, 3-83. [CrossRef]

24. Piyasena, P.; Mohareb, E.; McKellar, R. Inactivation of microbes using ultrasound: A review. Int. J. Food Microbiol. 2003, 87, 207-216. [CrossRef]

25. Jiranek, V.; Grbin, P.; Yap, A.; Barnes, M.; Bates, D. High power ultrasonics as a novel tool offering new opportunities for managing wine microbiology. Biotechnol. Lett. 2008, 30, 1-6. [CrossRef] [PubMed]

26. Guerrero, S.; López-Malo, A.; Alzamora, S.M. Effect of ultrasound on the survival of Saccharomyces cerevisiae: Influence of temperature, $\mathrm{pH}$ and amplitude. Innov. Food Sci. Emerg. Technol. 2001, 2, 31-39. [CrossRef]

27. Furuta, M.; Yamaguchi, M.; Tsukamoto, T.; Yim, B.; Stavarache, C.E.; Hashiba, K.; Maeda, Y. Inactivation of Escherichia coli by ultrasonic irradiation. Ultrason. Sonochem. 2004, 11, 57-60. [CrossRef]

28. Tsukamoto, I.; Yim, B.; Stavarache, C.E.; Furuta, M.; Hashiba, K.; Maeda, Y. Inactivation of Saccharomyces cerevisiae by ultrasonic irradiation. Ultrason. Sonochem. 2004, 11, 61-65. [CrossRef]

29. Borthwick, K.A.J.; Coakley, W.T.; McDonnell, M.B.; Nowotny, H.; Benes, E.; Gröschl, M. Development of a novel compact sonicator for cell disruption. J. Microbiol. Methods 2005, 60, 207-216. [CrossRef]

30. López-Malo, A.; Palou, E.; Jiménez-Fernández, M.; Alzamora, S.M.; Guerrero, S. Multifactorial fungal inactivation combining thermosonication and antimicrobials. J. Food Eng. 2005, 67, 87-93. [CrossRef]

31. Yap, A.; Schmid, F.; Jiranek, V.; Grbin, P.; Bates, D. Inactivation of Brettanomyces/Dekkera in wine barrels by high power ultrasound. Aust. N. Z. Wine Ind. J. 2008, 23, 32-40.

32. Porter, G.W.; Lewis, A.; Barnes, M.; Williams, R. Evaluation of high power ultrasound porous cleaning efficacy in American oak wine barrels using X-ray tomography. Innov. Food Sci. Emerg. Technol. 2011, 12, 509-514. [CrossRef]

33. Hromádková, Z.; Ebringerová, A. Ultrasonic extraction of plant materials-investigation of hemicellulose release from buckwheat hulls. Ultrason. Sonochem. 2003, 10, 127-133. [CrossRef]

34. Mason, T.; Paniwnyk, L.; Lorimer, J.P. The uses of ultrasound in food technology. Ultrason. Sonochem. 1996, 3, S253-S260. [CrossRef]

35. Sališová, M.; Toma, Š.; Mason, T.J. Comparison of conventional and ultrasonically assisted extractions of pharmaceutically active compounds from Salvia officinalis. Ultrason. Sonochem. 1997, 4, 131-134. [CrossRef]

36. Qiu, Y. Phénomènes de Transfert D'oxygène à Travers la Barrique. Ph.D. Thesis, Université de Bordeaux, Bordeaux, France, 2015.

37. Gindl, M.; Sinn, G.; Gindl, W.; Reiterer, A.; Tschegg, S. A comparison of different methods to calculate the surface free energy of wood using contact angle measurements. Colloids Surf. A: Physicochem. Eng. Aspects 2001, 181, 279-287. [CrossRef]

38. He, Z.; Wang, Z.; Zhao, Z.; Yi, S.; Mu, J.; Wang, X. Influence of ultrasound pretreatment on wood physiochemical structure. Ultrason. Sonochem. 2017, 34, 136-141. [CrossRef] [PubMed]

39. Qiu, Y.; Lacampagne, S.; Mirabel, M.; Peuchot, M.M.; Ghidossi, R. Oxygen desorption and oxygen transfer through oak staves and oak stave gaps: An innovative permeameter. OENO ONE 2018, 52, 1-14. [CrossRef]

40. Young, R.A. Wettability of Wood Pulp Fibers: Applicability of Methodology. Wood Fiber Sci. 2007, 8, 120-128.

(C) 2019 by the authors. Licensee MDPI, Basel, Switzerland. This article is an open access article distributed under the terms and conditions of the Creative Commons Attribution (CC BY) license (http:/ / creativecommons.org/licenses/by/4.0/). 